\title{
CLINICAL AND FUNCTIONAL CHARACTERISTICS OF YOUNG ADULT PATIENTS ADMITTED IN A STROKE UNIT
}

\author{
Marina Portugal Makhoul*, lara Maso**, Maiana Monteiro***, Isabella Rosa**, Lara \\ Vasconcelos*, Laísa Mascarenhas*, Pedro Antônio de Jesus****, Elen Beatriz Pinto*
}

\footnotetext{
Corresponding author: Marina Portugal Makhoul -mp_makhoul@hotmail.com

* State University of Bahia, Salvador, Brazil; BAHIANA - School of Medicine and Public Health- Group of research Motor Behavior and Rehabilitation Neurofuncional - Salvador, Brazil

** BAHIANA - School of Medicine and Public Health- Group of research Motor Behavior and Rehabilitation Neurofuncional - Salvador, Brazil; Roberto Santos General Hospital, Salvador, Brazil

*** BAHIANA - School of Medicine and Public Health- Group of research Motor Behavior and Rehabilitation

Neurofuncional - Salvador, Brazil

**** Roberto Santos General Hospital, Salvador, Brazil
}

BACKGROUND: Previously referred to as rare among young adults, in the last five years was found a frequency approaching $30 \%$ of young adults between those who have suffered a stroke in Brazil. OBJECTIVE: To identify the sociodemographic, clinical and functional characteristics of young adult patients. METHODS: It was a cross-sectional study, conducted with individuals assisted in a stroke unit with ischemic or hemorrhagic stroke diagnosis and age of 18-50 years old between August 2014 to April 2015. It was used the National Institutes of Health Stroke Scale (NIHSS), and the modified Rankin Scale (mRS). RESULTS: The study population consisted of 47 individuals, in which $28(59,6 \%)$ were female, with an average age of 39,2 (DP $\pm 8,3$ ) years, and brown skin color $21(44,7 \%)$. They presented 8,9 years of formal education. $28(59,6 \%)$ patients were diagnosed with ischemic stroke, $30(63,8 \%)$ had involvement of the anterior circulation, and $23(48,9 \%)$ of the left hemisphere. $26(55,3 \%)$ patients presented hypertension and $36(76,6 \%)$ were sedentary. The stroke severity had a median of 7 ( 0-23 ) points and $30(63,7 \%)$ of patients the functional was capacity 5 in the Rakin Scale. It was found a statistically significant difference for hypertensive etiology of hemorrhagic stroke in men $(p=0,047)$ when compared with gender and the occurrence of stroke in the right hemisphere in women $(p=0,032)$. CONCLUSION: The profile of the young adult patients from a stroke unit consists of female, of brown skin color, economically active with moderate stroke severity and severe functional disability.

Key Words: Stroke, Young adults, Disability, Stroke unit. 
BACKGROUND: Anteriormente considerado raro em jovens adultos, foi identificada uma frequência de $30 \%$ deste grupo demográfico entre sujeitos que sofreram acidente vascular encefálico nos últimos cinco anos. OBJETIVO: Identificar as características sociodemográficas, clínicas e funcionais de pacientes jovens adultos

MÉTODOS: Foi realizado um estudo transversal, com indivíduos atendidos em uma unidade especializada em AVE com diagnósticos de AVEs isquêmicos ou hemorrágicos e idade variando de 18 a 50 anos entre agosto de 2014 e abril de 2015. Foram usadas a National Institutes of Health Stroke Scale (NIHSS), e a Rankin Scale (mRS) modificada. RESULTADOS: A população do estudo consistiu de 47 indivíduos, entre os quais $28(59,6 \%)$ eram do sexo feminino, com idade média de 39,2 (DP+8,3) e 21 de pele parda $(44,7 \%)$. Eles possuíam em média 8,9 anos de educação formal. Vinte e oito pacientes $(59,6 \%)$ foram diagnosticados com AVE isquêmico, $30(63,8 \%)$ apresentaram envolvimento da circulação anterior, e $23(48,9 \%)$ do hemisfério esquerdo. Vinte e seis (55,3\%) pacientes apresentavam hipertensão e $36(76,6 \%)$ eram sedentários. A severidade do AVE teve uma mediana de $7(0-23)$ pontos e 30 $(63,7 \%)$ dos pacientes apresentaram capacidade funcional de 5 na escala Rakin. Foi encontrada uma diferença estatisticamente significante para etiologia hipertensiva no AVE isquêmico em indivíduos do sexo masculino ( $p=0,047)$ na comparação por gênero e a ocorrência de AVE no hemisfério direito em mulheres $(p=0,032)$. CONCLUSÃO: O perfil de pacientes jovens adultos na unidade especializada em AVE consiste em mulheres, de pele parda, economicamente ativas e com severidade moderada no AVE e severa incapacidade funcional.

Palavras-chave: Acidente Vascular Cerebral, adultos jovens, incapacidade funcional, Unidade de AVC. 


\section{INTRODUCTION}

According to the World Health Organization, the stroke is the second leading cause of death in the world, after ischemic heart disease'. In Brazil and other Latin America countries it is the leading cause of death ${ }^{2}$. The age group most commonly affected by stroke is between $70-80$ years old due to the aging of nervous and cardiovascular system ${ }^{3}$ associated with risk factors such as diabetes, hypertension, smoking, physical inactivity, dyslipidemia, heart diseases ${ }^{2}$, among others. Previously referenced as a rare condition among the young adults, with an incidence of 5 to $10 \%$, in Brazil, In the last five years have identified a frequency which is close to $40 \%$ of young adults between those who had stroke. ${ }^{6}$ In addition to the high mortality rate, it is considered as the most disabling of long-term diseases, impacting not only the patient but also their families ${ }^{7}$, and the social security and public system ${ }^{8}$ . The growing number of young adults affected by stroke has increased the cost of disability benefits, greatly burdening the public health budget and being responsible for $40 \%$ of early retirements ${ }^{8}$. Furthermore, the great etiology diversity for stroke in the younger population, diverging from the elderly population in relation to the most important risk factors, topography and most affected vascular territories ${ }^{9}$ justifies the need to extend studies on this population. The studies carried out in stroke units are not specifically aimed to this age group of the population, and a few national studies have characterized the population of young adults after stroke, which were performed in ambulatory services $^{3.6}$, one of hospital level ${ }^{10}$ or even survey by telephone ${ }^{11}$. Data from a unit specialized in the diagnosis and etiological investigation of stroke can increase knowledge of the behavior of this disease in this specific age group. The objective of this study was to identify the sociodemographic, clinical and functional characteristics of young adult patients treated at a stroke unit of a public reference hospital in Salvador, Bahia.

\section{MATERIAL AND METHODS}

This is a descriptive cross-sectional study, conducted with individuals assisted in a stroke unit of a public reference hospital in Salvador, Bahia. Patients included were diagnosed with ischemic or hemorrhagic stroke between 18-50 years old. The stroke was considered as a focal neurological deficit lasting more than 24 hours ${ }^{12}$ and confirmed by neuroimaging studies such as computed tomography and magnetic resonance imaging. The study excluded all patients who had some other neurological disease of degenerative, traumatic and / or infectious nature in addition to the confirmed diagnosis of transient ischemic attack. The primary data were collected through a form with the patient or family and the secondary data were obtained from hospital records. Sociodemographic characteristics collected in the study were age and education defined in years, gender, and family income, defined in number of Brazilian minimum wages. The occupational status was defined as activity, national social security beneficiaries, retired or unemployed, and the skin color was set in white, black or brown, by the researcher. Clinical characteristics dominance and comorbidity were identified. The High Blood Pressure (HBP) was when the systolic blood pressure was 140 $\mathrm{mmHg}$ and / or diastolic blood pressure was 90 $\mathrm{mmHg}^{13}$. Diabetes Mellitus (DM) was diagnosed when the fasting blood glucose was greater than $126 \mathrm{mg} / \mathrm{dL}$ or blood sugar higher than $200 \mathrm{mg}$ / $\mathrm{dL}^{14}$. The dyslipidemias are characterized, when the triglycerides are higher than $200 \mathrm{mg} / \mathrm{dL}$ total cholesterol greater than $240 \mathrm{mg} / \mathrm{dL}$ or HDL cholesterol less than $40 \mathrm{mg} / \mathrm{DL}^{15}$. Heart disease or atrial fibrillation (AF), both should be diagnosed by a doctor; obesity is considered when the body mass index is greater than $25 \mathrm{~kg} \mathrm{/} \mathrm{m}^{14}$. Chronic renal failure was diagnosed by the doctor and may be dialysis and non-dialysis dependent. As for lifestyle it was considered alcohol abuse, smoking and / or inactivity.

The clinical data of stroke based on medical diagnosis were the history of stroke and prior transient ischemic attack, stroke types, considered as ischemic, hemorrhagic, and also further classified as stroke and the injury site established as the right hemisphere, left hemisphere, cerebellum and / or brainstem. The affected vascular territory was classified as anterior and / or posterior circulation, defined by imaging. The etiologic diagnosis was made by the criteria of the Trial of ORG 10172 in Acute Stroke Treatment (TOAST) ${ }^{16}$ for ischemic stroke, which ranks as atherosclerosis of large arteries, cardioembolism, occlusion of small vessels, cryptogenic, more than one possible 
cause, certain other etiologies and for hemorrhagic stroke was described by the medical team. For the severity of stroke it was applied the National Institutes of Health Stroke Scale (NIHSS) ${ }^{17}$, containing 11 items: level of consciousness, language, neglect, visual field loss, eye movements, muscle strength, ataxia, dysarthria and sensory loss. This scale ranges from 0-42 and the lower the score, the less severe the stroke. The Modified Rankin Scale (mRS) was used to measure the degree of disability and dependence in post stroke daily activities. It is composed of 7 items being 0 to absence of symptoms, 1 to symptoms without disability, 2 to mild disability, 3 to moderate disability, 4 to moderate to severe disability, 5 to severe disability and 6 to death ${ }^{17}$ The Statistical Package for Social Sciences (SPSS) version 13.0 was used to structure the data sheet and statistical analysis. After the descriptive analysis of clinical, demographic and functional variables, a univariate analysis was performed comparing the clinical and functional characteristics between genders, so we used the chi-square test or Fisher's exact test for categorical variables and the Student $t$ test when was a normal distribution or Mann Whitney when was anormal distribution for continuous variables. The significance level was $5 \%(p<0.05)$. This study was approved by the Ethics Committee of BAHIANA - School of Medicine and Public Health under the number 725,135 , according to the Brazilian normative Resolution 466/12. All participants and / or guardians signed the Informed Consent form agreeing to participate in the voluntary survey.

\section{RESULTS}

From August 2014 to April 2015, 268 patients admitted to the stroke unit were evaluated. Among these 51 were aged 18-50 years old, however two were excluded for not having a confirmed diagnosis of stroke, and one due to a transient ischemic attack. Thus, the study population consisted of 47 individuals corresponding to a frequency of $17.4 \%$. Among these, $28(59.6 \%)$ were female, with a mean age of 39.2 years old (SD \pm 8.3$)$, being $21(44.7 \%)$ of skin color defined as brown, with average of 8.9 years of formal education (SD \pm 3.5 years). With regard to family income there was a median of 1.5 minimum wage and in relation to the occupation it was observed that $36(76.6 \%)$ were economically active. (Table 1 ).

Table 1. Sociodemographic characteristics of young adult patients admitted in a stroke unit of a public reference hospital in Salvador, Bahia, 2015.

Sociodemographic characteristics

Gender, n (\%)

Male

Female

Age, mean (SD)

Skin color, n (\%)

White

Black

Brown

Education (complete years of study), mean (SD)

Family income ( minimum wages), median(range)

Occupation , n (\%)

Activity

National social security beneficiaries

Retired

Unemployed
Total $(n=47)$

$19(40,4)$

$28(59,6)$

$39,2(8,3)$

$8(17,0)$

$18(38,3)$

$21(44,7)$

$8,9(3,5)$

$1,5(0,5-4,0)$

$36(76,6)$

$5(10,6)$

$1(2,1)$

$5(10,6)$ 
Ischemic stroke was diagnosed in 28 (59.6\%) patients and among these four (14.3\%) underwent thrombolytic treatment. When assessed the facility to manual ability, 43 (91.5\%) of them had right hand laterality. About the prior history of stroke, six $(12.8 \%)$ patients had had previous stroke and one $(2.1 \%)$ TIA. The etiologic classification of ischemic stroke noted that a majority of ten $(35.7 \%)$ patients were classified as cryptogenic, followed by seven $(25.0 \%)$ with certain other causes, six $(21.5 \%)$ with cardioembolism, one ( $3.5 \%$ ) with both occlusion of small vessels and atherosclerosis of large vessels, and three $(10.7 \%)$ were discharged to complete the investigation etiology in an outpatient ward.

Among the other certain causes three were classified $(42.9 \%)$ both with cerebral arterial dissection and venous thrombosis and one (14.3\%) with polycythemia. The hemorrhagic stroke had hypertension as the predominant etiology in eight
$(42.1 \%)$ of the patients, followed by undetermined causes in three $(15.7 \%)$ patients. The patients stayed in hospital for 10.4 (SD \pm 5.9 ) days. The other clinical characteristics are shown in Table 2. When assessing the functional capacity of patients by the modified Rankin scale at admission it was observed that $30(63.8 \%)$ patients had Rankin 5, followed by ten $(21.3 \%)$ with Rankin 4 (Figure 1)

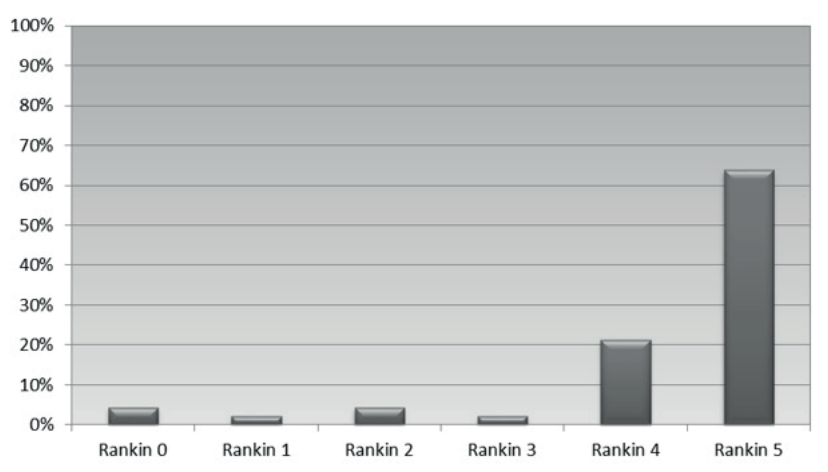

Figure 1. Modified Rankin Scale of young adult patients treated at a stroke unit of a public reference hospital in Salvador, Bahia, 2015.

Stroke type, n (\%)

Ischemic

Hemorrhagic

Vascular territories, $\mathbf{n}(\%)$

Anterior circulation

Posterior circulation

Both circulation

Site of stroke, n (\%)

Right hemisphere

Left hemisphere

Brainstem

Cerebellum

Both hemisphere

Hemisphere and cerebellum

Hemisphere and brainstem

$1(2,1)$

Cerebellum and brainstem

Etiologic Hemorrhic Strokea, n (\%)

Trombophilia

Hypertensive

Arteriovenous malformation

Cerebral venous thrombosis

Amyloid angiopathy

Undetermined

Incomplete evaluation 


\section{Clinical characteristics}

\section{Total $(n=47)$}

National Institutes of Health Stroke Scale at admission, median (range)

\section{Comorbidity, n (\%)}

Hypertension

$26(55,3)$

Diabetes Mellitus

Obesity

$8(17,0)$

Dyslipidemia

$4(8,5)$

Chronic renal failure non-dialysis dependent

Atrial fibrillation

Heart diseases

\section{Lifestyle habits, n (\%)}

Alcohol abuse

When compared gender to the clinical and functional characteristics, there was no statistically significant difference for the variables type of stroke, vascular territory, etiology of ischemic stroke, comorbidities, life habit, NIHSS and Rankin admission. (Table 3).

Table 3. Association of the clinical and functional characteristics between genders of young adult patients treated at a stroke unit of a public reference hospital in Salvador, Bahia, 2015.

\begin{tabular}{lccc}
\hline & \multicolumn{2}{c}{ Gender } & \\
Clinical and Functional Characteristics & Male & Female & $p$ \\
& $(n=19)$ & $(n=28)$
\end{tabular}

Stroke type, n (\%)

Ischemic

Hemorrhagic

$10(52,6) \quad 18(64,3)$

$0,424^{* * * *}$

$9(47,4) \quad 10(35,7)$

Vascular territories, n (\%)

Anterior circulation

$\begin{array}{rrl}11(57,9) & 19(67,9) & 0,485^{* * * *} \\ 7(36,8) & 6(21,4) & 0,246 * * * \\ 1(5,3) & 3(10,7) & 0,638^{* *}\end{array}$

Both circulation

$1(5,3) \quad 3(10,7)$

$0,246 * * * *$

Site of stroke, $\mathbf{n}(\%)$

Right hemisphere,

$\begin{array}{ccl}1(5,3) & 10(35,7) & 0,032^{* *} \\ 11(57,9) & 12(42,9) & 0,312^{* * * *} \\ 2(10,5) & 1(3,6) & 0,557^{* *} \\ 2(10,5) & 2(7,1) & 1,000^{* *} \\ 1(5,3) & 2(7,1 / 0 & 1,000^{* *} \\ 1(5,3) & - & 0,404^{* *} \\ 1(5,3) & - & 0,404^{* *} \\ - & 1(3,6) & 1,000 * *\end{array}$

Left hemisphere

Brainstem

Cerebellum

Bouth hemisphere

Hemisphere and brainstem

Hemisphere and cerebellum

Cerebellum and brainstem 


\begin{tabular}{lccc}
\hline & \multicolumn{2}{c}{ Gender } \\
Clinical and Functional Characteristics & Male & Female & $p$ \\
\hline
\end{tabular}

Etiologic Ischemic Stroke (TOAST), n (\%)

Large-artery atherosclerosis

Cardioembolism

$\begin{array}{cll}- & 1(5,5) & 1,000^{* *} \\ 3(30,0) & 3(16,6) & 0,674^{* *} \\ - & 1(5,5) & 1,000^{* *} \\ 2(20,0) & 8(44,4) & 0,168^{* *} \\ 3(30,0) & 4(22,2) & 1,000^{* *} \\ 2(20,0) & 1(5,5) & 0,557^{* *}\end{array}$

Small-artery occlusion

Cryptogenic

Other determined origin

Incomplete evaluation

$\begin{array}{cc}\text { Male } & \text { Female } \\ (n=19) & (n=28)\end{array}$

Ischemic Stroke of other determined origin, $\mathbf{n}(\%)$

Arterial dissection

$\begin{array}{ccc}2(66,6) & 1(25,0) & 0,557^{* *} \\ 1(33,3) & - & 0,404^{* *} \\ - & 3(75,0) & 0,262^{* *}\end{array}$

Polycythemia

Cerebral venous thrombosis

$3(75,0)$

$0,262 * *$

Etiologic Hemorrhic Strokea, n (\%)

Trombophilia

Hypertensive

Arteriovenous malformation

Cerebral venous thrombosis

Amyloid angiopathy

Undetermined

Incomplete evaluation

$\begin{array}{ccc}- & 1(10,0) & 1,000 * * \\ 6(66,6) & 2(20,0) & 0,047^{* *} \\ - & 1(10,0) & 1,000^{* *} \\ - & 1(10,0) & 1,000 * * \\ - & 1(10,0) & 1,000^{* *} \\ 2(22,2) & 1(10,0) & 0,557^{* *} \\ 1(11,1) & 3(30,0) & 0,638^{* *}\end{array}$

Comorbidity, n (\%)

Hypertension

$\begin{array}{ccc}12(63,2) & 14(50,0) & 0,373^{* * * *} \\ 2(10,5) & 2(7,1) & 1,000^{* *} \\ 1(5,3) & 7(25,0) & 0,119^{* *} \\ 1(5,3) & 3(10,7) & 0,638^{* *} \\ 2(10,5) & - & 0,158^{* *} \\ 1(5,3) & - & 0,404^{* *} \\ 4(21,1) & 3(10,7) & 0,417^{* *}\end{array}$

Diabetes Mellitus

Obesity

Dyslipidemia

Chronic renal failure non-dialysis dependent

Atrial fibrillation

Heart diseases

$4(21,1) \quad 3(10,7)$

$0,417^{* *}$

Lifestyle habits, n (\%)

Alcohol abuse

$8(42,1) \quad 6(21,4)$

$0,128^{* * * *}$

Physical inactivity

Smoking

$16(84,2) \quad 20(71,4)$

$0,310 * * * *$

$5(26,3) \quad 4(14,3)$

$0,453^{* *}$

Length of stay, mean (SD)

$9,9(5,2) \quad 10,8(6,5)$

$0,642 *$

NIHSS at admission, median (range)

$7,0(0-23) \quad 7,0(0-23)$

$0,591^{* * *}$

Modified Rankin Scale, median (range)

$5(0-5) \quad 5(0-5)$

$0,509 * * *$

*Student $t$ test $* *$ Fisher's exact test ***Mann Whitney test **** Chi-square test 
Statistically significant difference was found at the site of injury, and observed that women had a higher incidence in the right hemisphere, 10 $(35.7 \%)$ women and $1(5.3 \%)$ man, with $p=0.032$. As well as in relation to etiology of hemorrhagic stroke it was observed that men had a higher frequency of hypertensive etiology, $6(66.6 \%)$ men and $2(20 \%)$ women, with $p=0.047$. (Table 3)

\section{DISCUSSION}

The frequency of young adults observed in this study, whose age group included individuals aged between 18 to 50 years is close to those found in other Brazilian studies, ranging from 16 to $41 \% \%^{6,11,18}$. In studies conducted in developed countries, who consider the young adult population between 18 and 45 years old ${ }^{4,19,20}$ the incidence ranges from 5 to $10 \%$. The greater control of modifiable risk factors in these countries may explain this difference. Formal education was also equivalent to that found for the young Brazilian population. Despite the increase in average years of study, according to the Brazilian Institute of Geography and Statistics ${ }^{21}$ it is observed that even with an increase in the level of education of individuals, clinical risk factors still show as the main cause of the disease ${ }^{19}$.

The higher frequency of females observed in this study, confirms the research conducted on national territory $3,6,10$, including a study in the city of Salvador ${ }^{22}$. No statistically significant difference of clinical characteristics between genders have been noted in the female population of this study, yet a combination of risk factors including a high rate of hypertension and sedentary lifestyle, higher frequency of obesity and diabetes compared to men were present in the sample. Data of the world population report these characteristics and confirm the prevalence of stroke in women ${ }^{23}$. The skin color is not well known in the population of young adults who suffered strokes, but in the general population its relation with the event is already established ${ }^{24}$. In the present study the brown color was the most frequent, followed by black, with a study that addresses this aspect and the black color appears most frequently, followed by brown skin color ${ }^{22}$. American data Heart Association and American Stroke Association reveal that afro descendants are three times more at risk of suffering the first stroke event than white people ${ }^{24}$. In a biological perspective, theories discuss the relationship of hypertension to race, one of them suggests that African descent individuals who have gone through an adverse process as slavery, tend to have the presence of genes for salt retention, which would provide a selective advantage, but which becomes harmful out of its original context. In populations of the same race who experienced a different context, these genes are less found ${ }^{25}$. In this study most of the young adults of the stroke unit had severe functional disability, and impaired functional capacity, a condition that has consequences for the quality of life of the patient that is also affected by fatigue, depression and unemployment ${ }^{26}$. Most of the population of this study was in full socioeconomic activity, corroborating the studies of Park et al. ${ }^{19}, 2014$, conducted by 29 Korea Information emergency system with 1,431 young adults which identified $74 \%$ of individuals evaluated in work activity. Stroke is a disabling disease ${ }^{7}$ and the involvement of this active population will bring losses to social security, reaching a rate of $40 \%$ of early retirement ${ }^{8}$ with a range of 40 to $93 \%$ of patients not returning to previous activity, requiring permanent removal from professional activities ${ }^{11.2728}$. Another aspect still rarely discussed in the literature is the site of injury in this specific population. In this investigation the involvement of the left hemisphere was the most frequent, similar to what has been documented in a study of young adult population in ambulatory ${ }^{22}$. In the meantime it hasn't been identified in the literature any explanation for the right hemisphere lesion prevalence in women in this study. The severity of stroke, as well as the impact on functional capacity may be related to lesions in both hemispheres. In this study the majority of patients at the time of admission showed a moderate stroke severity according to the NIHSS, which is in consonance with Rena et al. ${ }^{9} 2014$, a study conducted on a stroke unit in Italy, which evaluated 150 patients young adults. When compared the types of stroke, the greater frequency of ischemic stroke in this study corroborates to what has been described in the literature $3,4,18,19,22$, in particular, the proportion of patients diagnosed with hemorrhagic stroke were mostly of hypertensive etiology, reasoning with the findings of previous studies ${ }^{3,4}$. There was a statistically significant difference when comparing female and male with hypertensive etiology of hemorrhagic stroke: the most hypertensive were 
men, presenting higher frequency of hemorrhagic stroke. In contrast, a study conducted in young adults who had suffered ischemic stroke from 15 European cities showed the relationship between smoking and dyslipidemia with the male 29, suggesting the need for preventive measures to avoid the occurrence and recurrence of stroke in this particular population ${ }^{29}$. The restricted sample collection accessible, according to specific clinical criteria for admission of patients in the unit, could be classified as a limitation of the study, not allowing extrapolating these results. We conclude that the outline of young adults from a stroke unit is of female individuals, of brown skin color, in socio economic activity with moderate stroke severity and severe functional disability.

\section{REFERENCES}

1. World Health Organization. Global Health Observatory data repositor. Mortality and global health estimates - estimates for 20002012 [Internet]. [cited 2016 May 06]. Available from: http://apps.who.int/gho/data/view.main. CODWORLDV? lang $=$ en.

2. Brasil. Ministério da Saúde. Secretaria de atenção à saúde. Departamento de atenção especializada. Manual de rotinas para atenção ao AVC. Brasília (DF). 2013. Portuguese.

\section{Zétola VHF, Nóvak EM, Camargo CHF,} Carraro HJ, Coral P, Muzzio JA, et al. Acidente vascular cerebral em pacientes jovens - Análise de 164 casos. Arq. Neuro-Psiquiatr. 2001 Sept;59(3B):740-745. doi: 10.1590/S0004282X2001000500017. Portuguese.

4. Cardoso T, Fonseca T, Costa M. Acidente vascular cerebral no adulto jovem. Acta Médica Portuguesa. 2003;16:239-24. Portuguese.

5. Leno C, Berciano J, Combarros O, Polo JM, Pascual J, Quintana F, et al. A prospective study of stroke in young adults in Cantabria, Spain. Stroke. 1993;24(6):792-795. doi: 10.1590/S0004282X2001000500017. Portuguese.

6. Sousa-Pereira SR, Braga CA, Garcia ED, Teixeira AL. Acidente vascular encefálico em adultos jovens: análise de 44 casos. Revista de Medicina de Minas
Gerais. 2010;20(4):514-518. Portuguese.

7. Patel MD, McKevitt C, Lawrence E, Rudd AG, Wolfe CDA. Clinical determinants of long-term quality of life after stroke. Age and Ageing. 2007; 36(3):316-22.

8. Plano de ações estratégicas para o enfrentamento das doenças crônicas não transmissíveis no Brasil 2011-2012. Brasília (BR). Ministério da Saúde. 2011 . Portuguese.

9. Rena R, Pilato F, Profice P, Marca DM, Broccolini $A$, Morosetti $R$, et al. Risk factor and etiology analysis of ischemic stroke in young adult patients. Journal of Stroke and Cerebrovascular Diseases. 2014 March;23(3):221-227. doi: 10.1016/i. istrokecerebrovasdis.2013.10.008.

10. Negrão ED, Brandi IV, Nunes SV, Tavorá DGF, Nakayama M, Beraldo PSS. Forame oval patente e Acidente Vascular Cerebral em jovens: Associação causal ou estatística? Arquivo Brasileiro de Cardiologia. 2007 May;88(5):5 14-520. doi: 10.1590/S0066-782X2007000500003. Portuguese.

11. Falcão IV, Carvalho EMF, Barreto KML, Lessa FJD, Leite VMM. Acidente vascular cerebral precoce: implicações para adultos em idade produtiva atendidos pelo Sistema Único de Saúde. Revista Brasileira de Saúde Materno Infantil. 2004 March;4(1):95-102. doi: 10.1590/S151938292004000100007. Portuguese.

12. National Institute of Neurological Disorders and Stroke. Special report from the National Institute of Neurological Disorders and Stroke: classification of cerebrovascular diseases III. Stroke. 1990;21(4):637-76. doi: 10.1161/01. STR.21.4.637

13. Sociedade Brasileira de Hipertensão [Internet]. O que é hipertensão [cited 2014 May 16]. Available from: http://www.sbh.org.br/geral/ oque-e-hipertensao.asp. Portuguese.

14. Brasil. Ministério da Saúde. Secretaria de Atenção à Saúde. Departamento de Atenção Básica. Diabetes Mellitus. Cadernos de Atenção Básica 16. Série A. Normas e Manuais Técnicos. 
Brasília (DF): Ministério da Saúde; 2006.

Portuguese.

15. Xavier HT, Izar MC, Faria Neto JR, Assad MH, Rocha VZ, Sposito AC, et al. V Diretriz brasileira de dislipidemias e prevenção da aterosclerose. Arquivos Brasileiros de Cardiologia. 2013; 101 (4Supl.1):1-22. doi: 10.5935/abc.2013S010. Portuguese.

16. Adams Jr HP, Bendixen BH, Kappelle LJ, Biller J, Love $B B$, Gordon DL, et al. Classification of subtype of acute ischemic stroke: definitions for use in a multicenter clinical trial. Stroke. 1993;24(1):35-41. doi: 10.1161/01.STR.24.1.35

\section{Cincura C, Pontes-Neto OM, Neville IS,} Mendes HF, Menezes DF, Mariano DC, et al. Validation of the National Institutes of Health Stroke Scale, Modified Rankin Scale and Barthel Index in Brazil: The role of cultural adaptation and structured interviewing. Cerebrovasc Disease. 2009;27(2):1 19-22. doi:10.1159/000177918.

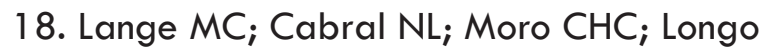
$A L$; Gonçalves AR; Zétola VF, et al. Incidence and mortality of ischemic stroke subtypes in Joinville, Brazil: a population-based study. Arquivo de Neuropsiquiatria. 2015;73(8):648-654. doi: $10.1590 / 0004-282 \times 20150081$.

\section{Park WB, Cho JS, Shin SD, Kong SY, Kim} JJ, Lim YS, et al. Comparison of epidemiology, emergency care, and outcomes of acute ischemic stroke between young adults and elderly in korean population: A multicenter observational study. Journal of Korean Medical Science. 2014;29(7):985-991. doi:10.3346/ jkms.2014.29.7.985.

20. Palleiro MMO, López BC. Subtipos etiológicos de accidente cerebrovascular isquémico en adultos de edades entre 18 y 45 años. Revista Clínica Española. 2007;207(4):158-165. Spanish.

21. Instituto Brasileiro de Geografia e Estatística (IBGE). Pesquisa nacional por amostra de domicilioSíntese de indicadores 2012. Rio de Janeiro. 2013. Portuguese.

22. Amorim DM. Características clínicas e fatores de riscos em pacientes jovens com acidente vascular cerebral [Trabalho de Conclusão de Curso]. Salvador: Universidade Federal da Bahia, Faculdade de Medicina da Bahia; 2012. Portuguese.

\section{American Heart Association and American} Stroke Association, 2014. Stroke Risk for Woman [Internet]. [cited 2015 September 13]. Available from: http://powertoendstroke.org/stroke-reducerisk-women.html.

\section{American Heart Association and American} Stroke Association. African americans and stroke [Internet]. [cited 2015 September 13]. Available from: http://powertoendstroke.org/stroke-africanamericans.html.

25. Laguardia J. Raça, genética \& hipertensão: nova genética ou velha eugenia? História, Ciências, Saúde-Manguinhos. 2005; 1 2(2):371-93. Portuguese.

26. Naess $H$, Waje-Andreassen $U$, Thomassen $L$, Nyland H, Myhr KM. Health-related quality of life among Young adults with ischemic stroke on longterm follow-up, Stroke. 2006;37(5):1 232-1 236. doi: 10.1161/01.STR.0000217652.42273.02.

27. Varona JF. Long-term prognosis of ischemic stroke in young adults. Hindawi Publishing Corporation. Stroke Research and Treatment 2011. 2011 1:1-5. doi: 10.4061/2011/879817.

28. Pinto EB, Maso I, Pereira JLB, Fukuda TG, Seixas JC, Menezes DF, et al. Differential aspects of stroke and congestive heart failure in quality of life reduction: a case series with three comparison groups. Health and Quality of Life Outcomes. 2011 ;9:65. doi: 10.1186/1477-7525-9-65.

29. Putaala J, Yesilot N, Waje-Andreassen W, Pitkäniemi J, Vassilopoulou S, Nardi K et al. Demographic and geographic vascular risk factor differences in european young adults with ischemic stroke: The 15 cities young stroke study. Stroke. $2012 ; 43(10): 2624-2630$. doi: $10.1161 /$ STROKEAHA.1 12.662866. 